Article

\title{
Ritual Void or Ritual Muddle? Deconsecration Rites of Roman Catholic Church Buildings
}

\author{
Kim de Wildt $\mathbb{D}$ \\ Transformation of Sacred Space: Function and Use of Religious Places in Germany (FOR 2733), \\ University of Bonn, 53113 Bonn, Germany; kdewild1@uni-bonn.de
}

Received: 29 August 2020; Accepted: 6 October 2020; Published: 10 October 2020

\begin{abstract}
The decrease in people who regularly celebrate liturgy in western Europe has led to the question of what to do with so-called obsolete church buildings. This question not only refers to whether or not a church building will be converted, reused or demolished, but also to the question of whether or not such a building needs to be deconsecrated, and if so, what does deconsecration of a church building actually entail? In this contribution, I will consider the role deconsecration rites play in the Roman Catholic church when a church building is taken out of liturgical use. In Roman Catholic liturgy, there are no prescribed, official deconsecration rites that are mandatory for a church building that is to be taken out of liturgical use. The actual deconsecration of a church building is, according to canon law, established by a decree that is issued by the responsible diocesan bishop. In the case of a church being taken out of liturgical use, however, there seems to be a shift from having a ritual void with regard to deconsecration rites, and also a focus on the "legitimate" way (in the sense of canon law) to deconsecrate a church building (object orientation), towards, in recent decades, paying more attention to a growing pastoral need (subject orientation) for deconsecration rites. These new ritual initiatives can be regarded as forms of pastoral care intended to help parishioners cope with the loss of their church building. I will show that different interpretations of canon law articles complicate straightforward answers to the question of which arguments are legitimate to deconsecrate a church. Furthermore, I will address the "ritual muddle", the mixture of the actual deconsecration act in the sense of canon law and deconsecration rites that, from the perspective of canon law, do not effect church deconsecration. I will also address the differentiation between desecration and deconsecration, address historical forms of deconsecration rites and pay attention to the making and unmaking of sacred space. Finally, I will focus on contemporary deconsecration rites against the background of the complex reality in which such rites are situated.
\end{abstract}

Keywords: deconsecration; desecration; consecration; profanation; church buildings; sacred space; church reuse; altar; Roman Catholic Church; canon law

\section{Introduction}

Against the background of a decline in number of people who partake in regular liturgical celebrations, as well as a decline in church finances, the question of what to do with the surplus of church buildings has become a pressing matter for several decades in western Europe (De Wildt and Plum 2019). The Dutch ritual studies scholar Paul Post speaks in this context of the fact that church buildings are becoming more and more of "a problem" and that there is a shift of interest from redesigning church interiors to the current problems of church vacancy and reuse (Post 2010, pp. 41-44). Post regards cases of:

“( ... ) redundancy, demolition, and disappearance of church buildings as the ultimate sign of disappearing ritual and, immediately in its wake, the sign of disappearing religion as well." (Post 2019, p. 46) 
These "disappearing" church buildings do, however, in most cases not disappear without some sort of last ritual, before indeed leaving a ritual void.

In this contribution, I will focus on the deconsecration of Roman Catholic church buildings in the context of canon law (CIC/1983), with reference to the making and unmaking of sacred space, before I focus on contemporary deconsecration rites. When a Roman Catholic church is taken out of liturgical use, whether or not it is to be reused, or in fewer cases, demolished, usually the church building is desacralized by a formal act of deconsecration or profanation. This specific aspect of "changing" the status of a sacred space into that of a profane or secular space can be read against the background of the recent transformations of sacred space that take place in western Europe (De Wildt et al. 2019).

The topic of church conversion or church reuse has been given much attention in recent decades (see for instance the extensive bibliography on the topic of church conversions of the Swiss Religious Heritage Day-Schweizer Kirchenbautag of the University of Bern: Literatur zu Kirchenumnutzungen n.d.). The literature on church reuse, however, focuses predominantly on the many best practice examples of and on how such reuse processes can be managed from the perspectives of architecture, monument conservation and real estate management. The theme of church deconsecration in literature, although sometimes implicitly mentioned, seems either overlooked, assumed clear or perhaps it is not addressed at all because it is regarded outdated. In this day and age, in which there seems to be a growing awareness that the simple dichotomy sacred-profane is not an apt representation of the far more intricate reality of sacred space, it may seem as if a discussion on church deconsecration in the sense of canon law is superfluous because it represents a worldview most of us have said farewell to. In my contacts with people in the field, however, predominantly in West Germany, who are confronted with the prospect of their church being reused and who are responsible for the process of taking a church out of liturgical use, many of the questions they ask are about deconsecration. In these conversations, a need to know how to actually deconsecrate a church, in the sense of canon law, is still expressed. From these conversations, I learned that there is a lack of knowledge on what church deconsecration in the Roman Catholic church actually entails. Some of the people in the field, often even experts, I spoke with, assumed for instance that deconsecration is the act of transferring the host from the tabernacle to a new church, whereas others were under the assumption that the last celebration of Mass effects the actual deconsecration of the church. Most of them wished for a clear-cut answer, they especially expressed a desire to know the church's institutional stance concerning church deconsecration with regard to canon law. Therefore, in this contribution, outdated as its subject may seem at first glance, I will address this topic in a manner that will highlight the complexities of church deconsecration. These complexities can partly be attributed to the shift in our understanding of what deconsecration rites are and what they are meant to accomplish. As I will show later on, there has been a shift in these rites from a perspective that focused on the "legitimate" way of deconsecrating a church to a perspective that concerns itself with the design of such rites for the wellbeing of the parishioners who are departing their church. These two aims have gotten mixed up, thus creating a ritual muddle in which it does not seem clear anymore what the actual function and status of such rites are, is it a way to undo the sacredness of a church building, or is it a ceremony that enables parishioners to cope with their feelings of loss and hurt? In most cases these two aims have gotten mixed up in one ritual, and therefore the ritual has become meaningless in the sense of canon law, since it is not a requirement for deconsecrating a church, and in a pastoral-liturgical sense as well because the focus on deconsecrating instead of focusing on dealing with the feelings of loss and transitioning makes it unclear what it is that is actually being ritualized here.

During my research on this topic, it soon became clear that there is no extensive literature on this topic, especially in contrast to the amount of literature there is on church reuse. There are some English-speaking contributions of canon lawyers, which I will present here, but the most extensive literature on this topic is in the German language. Here, the two German scholars of liturgical studies, Clemens Leonhard and Winfried Haunerland, proved to be the two main scholars that take on the problem of church deconsecration and deconsecration rites, not only from a historical perspective, 
but also from the perspective of the contemporary debates on church reuse. From my analysis of the English-speaking and German-speaking literature, I came to the conclusion that there are significant contradictions in the interpretation of the canon law articles that deal with church deconsecration. Moreover, the assessment of the German-speaking contributions showed that church deconsecration in the sense of canon law needs to be differentiated from deconsecration rites, rites that in fact have no part in bringing about the deconsecration of a church in the sense of canon law.

Canon law only recognizes three instances in which a church building is returned to a profane status: by its actual demolition, by the ongoing profane use of the building and by the disclosure of the deconsecration decree issued by the diocesan bishop (Haunerland 2016, p. 68).

There is, however, no official approved Roman Catholic rite for parish closure (Weldon 2004, p. xx). No formal rite is required for the deconsecration of a church building and there are no official deconsecration rites in the liturgical books issued by the Vatican, the issuing of a profanation decree by the responsible diocesan bishop suffices (Haunerland 2016, p. 68; Zimmerhof 2012, pp. 10, 19, 47-48; Leonhard 2012, p. 131). Still, there is a rise in the design of rituals for church buildings that are to be taken out of liturgical use. This ritual need is relatively new despite the fact that the closure of churches is not a new phenomenon (Simons 1998, p. 96).

\section{2. "Grave Reasons" for Relegating a Church Building to Profane Use}

Although church reuse is not a new phenomenon (De Wildt and Plum 2019, pp. 11-12), it has gained renewed interest in recent decades in those parts of the world that deal with a substantial decline in churchgoing, predominantly in western Europe. Nowadays a growing number of church buildings are considered obsolete, this is mostly attributed to declining numbers of people who partake in liturgical celebrations, to a shortage in priests and as a result of parish mergers. The Letter from the Congregation for the Clergy (Cardinal Piacenza and Iruzubieta 2013, p. 212) specifically states that:

" ( . . ) it is necessary to distinguish clearly between three separate and distinct canonical processes: (1) the modification of parishes, (2) the relegation to profane use and/or the permanent closure of churches, and (3) the alienation of current or former sacred edifices. Each process has its own procedures, and each must be followed carefully and correctly."

Here, the relation between parish modifications and church profanation and/or closure is clearly made by stressing the point that these processes should be clearly distinguished, whereas in reality, in a lot of cases, the question of the restructuring of parishes is actually closely related to the question of what to do with obsolete churches (Paprocki 1995). The parish modification, this letter states, must always be a matter of separate consideration and the decree must be motivated " $(\ldots)$ with a cause that is specific, i.e., ad rem, to the individual parish or church under consideration." Both procedures, parish modifications and church closure, require separate decrees (Cardinal Piacenza and Iruzubieta 2013, p. 212). Noteworthy is the fact that according to the Vatican canon lawyer Nikolaus Schöch, a reduction in numbers of people who celebrate the liturgy, priest shortage or the church being obsolete as a result of parish mergers are considered to be insufficient reasons for the relegation of a church to secular use (Schöch 2007, p. 494). The North-American canon lawyer, John M. Huels, however, refers to exactly two of these grounds-a decline in people who celebrate liturgy and a reduction in numbers of priests-as possible grave reasons that can be used as an argument to relegate a church to profane use (Huels 2000, p. 1432). Yet another canon lawyer, Thomas Schüller from Germany, states that economic problems, changed pastoral structures and the fact that churches are no longer needed constitute grave reasons (Schüller 2012, p. 273). The Procedural Guidelines for the Modification of Parishes, the Closure or Relegation of Churches to Profane but not Sordid Use, and the Alienation of the Same (hereafter: procedural guidelines) states on the basis of jurisprudence:

"that the following reasons in themselves do not constitute grave cause:

i. a general plan of the diocese to reduce the number of churches; 
ii. the church is no longer needed;

iii. the parish has been suppressed;

iv. the number of parishioners has decreased;

v. v closure will not harm the good of souls;

vi. a desire to promote the unity of the parish;

vii. some potential future cause that has not actually happened yet" (Cardinal Piacenza and Iruzubieta 2013, p. 217).

As shown here, we encounter all kinds of different interpretations, which are all based on the same canon law articles, of what may be considered grave reasons for a church to be relegated to profane use. At the conference “Doesn't God Dwell Here Anymore? Decommissioning Places of Worship and Integrated Management of Ecclesiastical Cultural Heritage", held in Rome at the Pontifical Gregorian University in November 2018, the Pontifical Council for Culture and the delegates of the episcopal conferences of Europe, Canada, the United States and Australia approved guidelines for ecclesial communities (Guidelines 2019) (hereafter: Vatican guidelines). In this document, the juridical complaints that may arise when a church is relegated to profane use on the base of jurisprudence are addressed. One of these problems is the reduction of

"a church to profane use without any of the necessary grave causes (today this is almost always identified with the impossibility of safely maintaining a building" (Guidelines 2019, p. 277).

Here, the "grave cause" is equated with the impossibility of maintaining a building safely and no other examples of what may constitute "grave cause" are referred to.

As we see, in the case of the Roman Catholic church the question of how to deconsecrate a church is usually answered with reference to canon law. In order to answer the question how to undo the sacredness of a church building, we first have to redirect our attention to the question: how does a church building actually become sacred according to canon law?

\section{The "Sacredness" of Church Buildings}

The Swiss canon lawyer René Pahud de Mortanges outlines the fact that the rules according to canon law with reference to church buildings are derived from a theological understanding of church buildings. From a functional stance, it is a place that enables the liturgical assembly, but from the point of view of canon law it is considered a sacred space. Said sacredness is derived from the Roman Catholic understanding of the Eucharist, which symbolizes the lasting presence of God and which expresses itself in the performance of Mass and the presence of the host in the tabernacle (Pahud de Mortanges 2007, p. 187; Leonhard 2012, p. 127).

From the perspective of canon law:

"Sacred places are those which are designated for divine worship or for the burial of the faithful by a dedication or a blessing which the liturgical books prescribe for this purpose." (can. 1205).

Specifically, with regard to church buildings, the Code of Canon Law (1983) stipulates the following:

"By the term church is understood a sacred building designated for divine worship to which the faithful have the right of entry for the exercise, especially the public exercise, of divine worship." (can. 1214).

The following articles specifically refer to the rites that are implemented to "make the church sacred":

"After construction has been completed properly, a new church is to be dedicated or at least blessed as soon as possible; the laws of the sacred liturgy are to be observed." (can. $1217 \S 1$ ). 
"Churches, especially cathedrals and parish churches, are to be dedicated by the solemn rite." (can. 1217 §1).

A church building, according to canon law, becomes a sacred place by the rite of dedication with chrism, which is a "solemn rite", or by the rite of blessing, which is a "less solemn rite". In both cases, this ritual act is recorded in parish and diocesan records. The term "dedication" is normally used with regard to both rites to refer to the change of status of a church building from a secular building into a sacred space (Schöch 2007, p. 485). The more solemn rite is used to dedicate more important churches such as cathedrals and parish churches. Less important spaces such as chapels may only be dedicated by the less solemn rite. Buildings that are only occasionally used for liturgical means do not require any ritualized form of dedication (Schöch 2007, p. 486). Churches are dedicated or blessed following the Rite of Dedication of a Church and an Altar (1978), which in fact consists of several rites such as the dedication and blessing of a church (Huels 2000, p. 1425). Without a dedication or blessing, a church is not considered sacred and Mass may not be celebrated there, the exception being only in case of need (Huels 2000, p. 1430). On where the Eucharist may be celebrated, canon law states the following:

"The eucharistic celebration is to be carried out in a sacred place unless in a particular case necessity requires otherwise; in such a case the celebration must be done in a decent place." (can. 932 §1) and

"The eucharistic sacrifice must be carried out on a dedicated or blessed altar; outside a sacred place a suitable table can be used, always with a cloth and a corporal." (can. 932 §2).

Since can. 932 states that Mass may be celebrated in all decent places, the only conclusion that can be drawn here is that, interestingly enough, the only place where Mass may not be celebrated is a deconsecrated church building.

\section{The "Sacredness" of the Altar}

As Schöch (2007, p. 502) explicitly points out, it is important to note that in can. $1238 \S 1$ it is stipulated that an altar can lose its dedication or blessing according to the norm of can. 1212-in the case of a major destruction, the church being given over permanently to profane use in its factual use or by decree- but that, according to $\$ 2$ of the same article:

"Altars, whether fixed or movable, do not lose their dedication or blessing if the church or other sacred place is relegated to profane uses." (can. 1238 §2).

Altars are dedicated in a separate rite (can. 1237 \$1) and need to be deconsecrated separately if a church is to be reused. If, in the case of a partial reuse, one still would want to have the option to celebrate Mass, Schüller considers that one could refrain from the deconsecration of the altar to leave this option available. It is possible to deconsecrate parts of the church and still continue to celebrate Mass in the consecrated parts of the church (Schüller 2012, pp. 272, 276). In such cases in which a church is deconsecrated, the still dedicated or blessed altar may be moved to and used in another church without being dedicated or blessed anew. In the case of desecration, can. 1211 takes effect (Huels 2000, pp. 1439-1440). In the procedural guidelines it is stated that:

"Even more so, altars do not lose their dedication or blessing when the church does, and can never be turned over to profane use for any reason (cf. cann. 1212 and 1238)." (Cardinal Piacenza and Iruzubieta 2013, p. 216).

According to the procedural guidelines:

"Prior to alienation, all sacred objects, relics, sacred furnishings, stained-glass windows, bells, confessionals, altars, etc. are to be removed for use in other sacred edifices or to be stored in ecclesiastical custody. Because altars can never be turned over to profane use, if they cannot be removed, they must be destroyed (cf. cann. 1212 and 1238)." (Cardinal Piacenza and Iruzubieta 2013, p. 219). 
The Vatican Guidelines state the following concerning the canonical practice of destroying altars:

"Concerning altars, the canonical practice of destroying the table in some cases can find itself in clear opposition to civil norms concerning the conservation of cultural heritage." (Guidelines 2019, p. 277).

Two sentences prior, however, it is stated that it is:

"necessary to consider some issues usually connected to the process of reduction of a church to a profane use $(\ldots)$ the need to avoid situations that can give offence to the religious sentiment of a Christian people" (Guidelines 2019).

It is not hard to imagine that the willful destruction of the altar could offend the religious sentiment of the faithful...

\section{The "Unmaking" of Sacred Space: Desecration and Deconsecration}

The "unmaking of sacred space" (Della Dora 2016) presupposes that sacred space was "made" at some point in time and therefore can be "unmade". As the cultural geographer Veronica Della Dora points out, transformation processes in western Europe, such as the conversion of church buildings, are changing the current landscape. These processes, as Della Dora states, can shed light on:

“ $(\ldots)$ the contestations between different grounded theologies and on the fluidity of the boundaries between sacred and secular, or rather, on the complex coexistences between the two." (Della Dora 2016, p. 45).

She discerns between desacralization-sacred places returning or transforming into secular uses—and desecration: sacrilege, willful destruction, defilement, in short:

“( ... ) a violent breach of the rules of behavior towards sacred things ( ... )" (Della Dora 2016, p. 45).

Della Dora regards these contemporary transformed sites of worship as expressions of social and cultural transformations, as well as:

"transformed relationships to sacred space, and of shifting perceptions of the sacred itself."

(Della Dora 2016, p. 46).

With the use of Eliades' sacred and profane distinction, she shows that in this line of thought there has been much emphasis on the "making" of sacred space. However, since the 1990s the academic understanding of sacred space shifted more towards regarding such spaces as places that are socially constructed instead of being products of theophanic events (Della Dora 2016, pp. 50ff). Della Dora shows furthermore that desacralization, or the unmaking of sacred space, is not a purely modern, western phenomenon, but a phenomenon that has a long history and is not confined to any specific area in the world (Della Dora 2016, pp. 54ff). In her focus on converted churches in contemporary western Europe, she states that these new processes of desacralization strongly differ from past ones because of:

" (... ) the privatization, museification and commodification of the sites, alongside an increasing tendency to adapt them to secular use, or to a mix of religious and non-religious functions ( ... )" (Della Dora 2016, pp. 60-61).

Bearing this in mind, the desacralization of sacred space is not an undisputed phenomenon. Whereas it may seem, at first glance, unambiguous to deconsecrate a church in the sense of canon law, the question remains if a church is indeed a profane space after the act of deconsecration. If one were to apply the line of abductive reasoning by means of the well-known duck test: "If it looks like a duck, swims like a duck, and quacks like a duck, then it probably is a duck" to a church building 
that has been deconsecrated according to canon law, one would probably still regard such a profaned building a church or at least a sacred space in most senses of the word. The Vatican guidelines make the following observation:

"Sacred buildings are a visible sign of the presence of God in a society that is today more and more secularized and simultaneously multireligious. They often have a role in giving quality to an urban or rural environment, as well as in giving structure to that environment in architectural terms. Their evangelizing readability remains even if they lose their liturgical functionality." (Guidelines 2019, p. 281).

Moreover, even canon law concerning the reuse of church buildings is not as clear-cut as one would presume because, in addition to it being interpreted differently and even contrary among canon lawyers, the fact that even when a church is relegated to profane use, this new use may never be sordid according to can. $1222 \S 1$, seems to imply that it is recognized that even after deconsecration a church building still cannot be considered a secular building as any other.

Winfried Haunerland also rightly points to the remarkable fact that any form of reuse or complete deconsecration actually contradicts the dedication rite, since the texts of the dedication rite imply that a church building is dedicated for all times (Haunerland 2011, p. 246). Clemens Leonhard also mentions the paradox of extinguishing inextinguishable sacredness, which in his assessment is something that can only be addressed, but not actually dissolved in a deconsecration celebration (Leonhard 2012, p. 147).

In the context of un-dedicating a sacred space according to the Code of Canon Law (1983), we can discern three dimensions: first, such a space loses its dedication because it suffers major destruction. Second, it loses its dedication if such a space is factually given over to profane use. Third, it loses its dedication if the space is relegated to profane use by the issuing of a decree of the bishop (Weldon 2004, p. 52). The articles can. 1211 and can. 1212 refer to such instances in which rites need to be performed to reinstate the sacredness of the place when its sacredness has been violated:

"Sacred places are violated by gravely injurious actions done in them with scandal to the faithful, actions which, in the judgment of the local ordinary, are so grave and contrary to the holiness of the place that it is not permitted to carry on worship in them until the damage is repaired by a penitential rite according to the norm of the liturgical books." (can. 1211).

"Sacred places lose their dedication or blessing if they have been destroyed in large part, or have been turned over permanently to profane use by decree of the competent ordinary or in fact." (can. 1212).

It is important to discern between the violation or desecration of a church building because of unworthily treatment, and a case in which a church building will be taken out of liturgical use, which is on the part of the church an intentional act. Both these extremes need to be differentiated from the intentional symbolical demolition of parts of the church building. This last aspect will be addressed later on.

"If a church cannot be used in any way for divine worship and there is no possibility of repairing it, the diocesan bishop can relegate it to profane but not sordid use." (can. 1222, §1).

"Where other grave causes suggest that a church no longer be used for divine worship, the diocesan bishop, after having heard the presbyteral council, can relegate it to profane but not sordid use, with the consent of those who legitimately claim rights for themselves in the church and provided that the good of souls suffers no detriment thereby." (can. 1222, §2).

Mostly the words "desacralization", or "deconsecration" are used to designate profanation in the context of can. 1222 and the words "violation" or "desecration" are used in the context of can. 1211. In the case of the desecration of a church, a penitential rite of reparation should be performed as soon 
as possible, ideally by the diocesan bishop. In the meantime, no other rite may be performed in the church. Preaching and devotional exercises should prepare the faithful for the rite of reparation (Huels 2000, p. 1427). In the case of a destruction of the building, to which can. 1212 refers, the church would lose its dedication. In the case of a major restauration in which a new altar is constructed, a new dedication or blessing of the altar is also required (Huels 2000, p. 1427).

\section{The Deconsecration of Sacred Space: Procedures and Reality}

In Canon 1212, it is stipulated that the diocesan bishop is the one who has the authority to decide whether a building intended for liturgy may be used in other ways (Weldon 2004, p. 55). Only the diocesan bishop has the authority to decide if a church is relegated to profane use, even if the church building is owned by a juridic person other than the parish or diocese (Huels 2000, p. 1432). Other "grave causes", as addressed in can. $1222 \$ 2$, allow for the bishop to relegate a church to profane use, but still some requirements should be met, information needs to be gathered in order to determine the reason for the relegation, the bishop has to consult the presbyteral council, he needs to get the consent of those who have legitimate claims to the church (see also can. 50) such as other owners of the church property, also the founders and their heirs (in a field study I conducted a group of churchgoers who objected the sale and demolition of their church wanted to make use of the argument that the founding deed of the church stipulated that its founder had his eternal resting place there (De Wildt 2019, p. 55)) (Schöch 2007, pp. 497-500). Whereas Schöch also includes financial donors who made substantial donations for the church building in the category of those who may have legitimate claims (Schöch 2007, p. 498), Huels specifically excludes this category (Huels 2000, p. 1433). Furthermore, the bishop has to determine that the good of the souls is not harmed by this act. Finally, in accordance with local and cultural circumstances the new use may not be sordid (Huels 2000, pp. 1432-1433; Schöch 2007, pp. 497-500). The meaning of the "good of the souls" and the non-"sordid use" are held vague, according to Schüller. The argument that the good of the souls could be harmed—one might argue this, if there is for instance a massive protest on the side of the parish members against church closure-is counteracted if the bishop is able to explain that the affected faithful still can depend on pastoral care after the church is closed. Any appeal against the decision of the bishop hardly stands a chance, according to Schüller (Schüller 2012, pp. 273-74).

The term "sordid" refers to such uses that are contrary to Christian morality (Schöch 2007, p. 486). The procedural guidelines state that:

"Under no circumstances can the edifice be alienated for use inconsistent with its inherent dignity as a former church. Contractual agreements are to be put in place to safeguard this point in civil law as well as canonically." (Cardinal Piacenza and Iruzubieta 2013, p. 218).

A problem may, however, arise if the church is resold again to a second owner and there is no way of safeguarding that the church will not be used in a "sordid" manner. Moreover, what actually constitutes a "sordid use" is nowhere explicated and this poses a problem for the stakeholders who do not only have to determine what forms of reuse are possible from the perspective of architecture, from a financial point of view and from the point of view of monument preservation, but who also have to take into consideration that such a use may not be "sordid". The German Bishops Conference issued a document in 2003 on church reuse in which it offers guidelines and a whole spectrum of possible forms of reuse ranging from a small transformation in which the church remains the owner of the building and few adjustments are made to the sale, or partial demolition, or ultimately complete demolition of the building. In this document the preference is formulated that a church is preferably sold to a public authority for public and cultural uses rather than to a commercial partner, although the document explicitly states that a commercial use may not be ruled out as an option. The document states further that the dignity of the space limits secular uses ("Die Würde des Raumes setzt der profanen Nutzung Grenzen."), but it is stipulated nowhere what these actual limits are (Umnutzung 
von Kirchen 2003, pp. 16-22). Although this document does not provide clarity as to what forms of use may be considered sordid, it provides some insight in a form of use that is prohibited: the liturgical use of a former church by non-Christian religious communities. The document names as examples Buddhism, Islam and sects (Umnutzung von Kirchen 2003, pp. 18-22). The Vatican guidelines also mention the term "sordid" and here it is referred to as:

"planning for an improper use ("sordid" cf. canon 1222) of a church after its reduction to profane status" (Guidelines 2019, p. 277).

I have described the way in which churches are deconsecrated in the sense of canon law, but when we focus on the actual practice of church deconsecration, it seems that the situation is even less straightforward. The German scholar of liturgical studies Albert Gerhards shows that in specific cases churches may very well be deconsecrated in the sense of canon law, such as has been the case with the church St. Nikolaus in Aachen, but that after deconsecration, Mass is still regularly celebrated in the choir of the church. The same applies to the "Grabeskirche" St. Josef, a church that is situated in Aachen as well, where Mass is still celebrated regularly in the choir after it has been deconsecrated. An opposite example is the church building "Kreuzung an St. Helena" in Bonn, a church that has been repurposed as a cultural meeting center, but that has never been deconsecrated (Gerhards 2020).

\section{Deconsecration Rites: Past}

The North-American pastoral theologian Michael Weldon makes the following critical observation concerning the profanation decree:

"This mandate $(\ldots)$ terminates a building's blessing by the simple declaration of the local Bishop. This reflects good ecclesial order but perhaps an unbalanced ritual mathematics-an inflated sense of the performance power of an official declaration. With all the ritual prescribed for the dedication of a building, a ritual density during its lifecycle, the accomplishment of its closure with a simple episcopal declaration lacks a ritual sense. Major levels of ritual make a parish; so little is required to unmake it." (Weldon 2004, pp. 52-53).

Weldon, based on his experiences as a pastor involved in the reorganization of parishes and the subsequent church closures, analyzed such conflict-laden processes and designed rites to help people cope with the trauma church closure may cause. In the context of church desecration Weldon makes reference to the penitential rite of reparation and describes pre-Vatican II medieval rites, which:

“( ... ) prescribed elaborate ceremonies if a building was profaned. These included 'lustrations' - blessings with baptismal water, later 'Gregorian' water (water, salt, ashes, and wine), a circling of the building's exterior with lament psalmody, the washing of the place of defilement with blest water and the singing of the Litany of the Saints." (Weldon 2004, p. 132).

Winfried Haunerland states that there has never been an Ordo; a binding order of liturgical acts within Roman Catholic liturgy, in the Pontificale Romanum or the Rituale Romanum for church deconsecration and that all known sources are of a local diocesan nature (Haunerland 2016, p. 83). He also points to the fact that although the Roman liturgical books before Vatican II did not contain any rules or regulations concerning deconsecration rites, there were West German liturgical books from the first half of the 20th century that did describe rites for the demolition of consecrated altars and consecrated churches (Haunerland 2016, p. 69). These rites mainly focused on the deconsecration of the altar. The priest, on explicit instruction of the bishop, should, together with other priests, kneel down in front of the altar, and pray silently the Lord's Prayer and Ave Maria, thereafter Antiphon, Versicle and Oration of the Saint were to be recited out loud. The altar stone or altar mensa should then be removed without damaging it and washed off by the priest. Haunerland assumes that this washing is a ritual withdrawal of the initial anointment, since this "washing off" is also described in the 1913 published journal Ephemerides Liturgicae with reference to the twelve anointed crosses (Haunerland 
2016, pp. 70-71). The relics are to be removed with extreme care from the altar(s). Although the altar deconsecration is the central act, when it comes to chapel or church deconsecration as a whole, there are further references on how to deal with this ritually, a few days before the physical destruction of the church, relics should be transferred to another, by the bishop designated, church. This transfer in some cases is conducted by the clergy as well as the faithful in a procession. Statues and images of saints should be transferred as well. These transferals should be conducted before the altar is deconsecrated (Haunerland 2016, pp. 71-72).

A detailed historical overview of profanation rites is provided by the theologian Christine Zimmerhof in her contribution on liturgy of church profanation (Zimmerhof 2012). Zimmerhof describes rites of reconsecration ("Wiedereinweihung") after a church has been desecrated in the time until the decretals of Gregory IX in 1234 AD. A church could lose its dedication by events such as the demolition of the church or of the altar, the removal of the altar, the shedding of blood, murder, or the sinful outpour of human semen (Zimmerhof 2012, pp. 12-16). With the issuing of the decretals, a source of canon law, the reasons for reconsecrating a church were reduced, only through the demolition of the main part or the complete structure of a church building, could the building lose its consecration. Other violations could be repaired by purification rites. Until the time of the Council of Trent, the secular use of a church building was something undesired by the church and all measures were taken to upkeep all churches and church reuse, as we have come to know it nowadays, was unthinkable. The preferred solution when a church could not be preserved was that it would be demolished and many churches were indeed demolished with reference to the Council of Trent. Trent did not stipulate how a church deconsecration should be ritually conducted, the only stipulation was that an immovable crucifix should be erected at the place where the church once stood (Zimmerhof 2012, pp. 16-19). After Trent, several diocesan initiatives emerged such as the rules that had to be observed in case of church and altar profanation as described in the Acta Ecclesiae Mediolanensis, and more specifically therein the description of the deconsecration rite De ratione adhibenda in Ecclesiis, Altaribusque profanandis of bishop Charles Borromeo in 1576. In this document, the actual profanation rite, which took several days, is described and this rite consists of the transfer of relics and statues to another church, the assembly of the clergy of the old church, as well as the clergy of the new church and the faithful, the demolition and removal of altars, the exhumation of bones, the procession to the new church, and the erection of a crucifix at the place where the church was situated as a permanent remembrance. Zimmerhof argues that pastoral-liturgical elements did play a role in this rite since the faithful move to the new church in a procession and also aid in exhuming the dead. It is noteworthy, according to Zimmerhof, that there is no mention of the celebration of the last Mass or the removal of the host from the tabernacle, whereas the transfer of the relics and statues are given a lot of attention. The demolition of the altar seems to be the decisive act that deconsecrates the church. The issuing of a profanation decree is not mentioned in the document (Zimmerhof 2012, pp. 19-22). The remarkable fact that the Eucharist is not mentioned anywhere in the older liturgical books in relation to church deconsecration could, according to Haunerland, be explained by the fact that in these historical cases, most church buildings may have already not been in use for a long time (Haunerland 2016, p. 78). Zimmerhof furthermore describes the rite of altar deconsecration in the 1591 published Ornatus ecclesiasticus of Jacob Müller, which is partly based on the document of Borromeo, which is more detailed. In this document, it is described that the altar should be prepared as if a Mass were to be celebrated there. The religious official conducts several rites in word (prayers, creed) and act (kneeling down, extinguishing candles, removing statues, washing the altar, removing the relics from the altar, demolishing part of the stipes of the altar with a hammer) (Zimmerhof 2012, pp. 25-28). Zimmerhof also describes the way in which two other historical documents deal with altar exsecration, such as a 14th century Mainz pontifical (Zimmerhof 2012, pp. 28-29), and the deconsecration regulation of the Münster diocesan synod of 1655 (Zimmerhof 2012, pp. 29-30). The deconsecration regulation of the Paderborn diocesan synod of 1688 also deals with altar exsecration, but with church or chapel deconsecration as well. Relics and statues and images of saints must be transferred to another, by the bishop designated, church in the presence 
of the faithful and the clergy of the church it is to be transferred too. After the exsecration rite, the altars should be destroyed and a crucifix should be erected where the church once stood (Zimmerhof 2012, pp. 30-34). Other local West German deconsecration rites document slight variations of the Paderborn synod of 1688 (Zimmerhof 2012, pp. 34-36). The final historical example Zimmerhof presents is the above mentioned in 1913 published deconsecration rite in the journal Ephemerides Liturgicae, which also refers to the Acta Ecclesiae Mediolanensis and which corresponds for the most part with the rite that has been described there. It differs from that rite in the sense that the bishop as initiator and overseer of the rite is not mentioned here and neither are the faithful or the clergy of the new church. In the 1913 rite, the altar exsecration is, for the first time, not the only act that effects the deconsecration of the church, but also the removal and washing of the twelve crosses on the walls should establish this (Zimmerhof 2012, pp. 36-37).

\section{Deconsecration Rites: Present}

Dedication rites, according to Weldon, are rooted in ritual traditions of Eucharistic celebrations, funerals, exorcism and initiation, and so too are the more recent, newly designed un-dedication rites he experienced (Weldon 2004, p. 111). Nowadays these rites focus more on the meaning of the rite for the wellbeing of the parishioners than on the proper and legitimate ritual way of deconsecrating a church building (Weldon 2004, pp. 126-27).

The Canadian scholar of liturgical studies, Lizette Larson-Miller, gives a vivid account of the merger of four Roman Catholic parishes into one new parish and the move of these parishioners into a new built cathedral: The Cathedral of Christ the Light in Oakland, California (Larson-Miller 2010). Although her study does not explicitly deal with church deconsecration, it does provide insight in the complexities of parish mergers and the transition to a new church, especially in this case, in which four different parishes who are merged into one all have very different backgrounds, cultures, and theological and political emphases. For instance, the renaming of the community led to fears of losing their own identity (Larson-Miller 2010, p. 219) and the hanging of a crucifix from one of the former churches in the new church, an act that had not been permitted, became a representation of the fear of loss of "their parish, their liberal and progressive Catholic standing, their carefully maintained simplicity of space, their hard work at balance between communities and their baptismally-based call to be leaders of their own worshipping community" (Larson-Miller 2010, p. 221) for some parishioners. The replacement of the baptismal font and the adding of statues, as well as a lack of communication, were all reasons for people to get upset (Larson-Miller 2010, p. 221). Lawson-Miller describes a meeting, initiated by the ordained community leaders, which was:

“( ... ) a response to the out-pouring of confusion and hurt (... ), and to attempt to move forward." (Larson-Miller 2010, p. 225).

In her analysis, Lawson-Miller shows that the parishioners from the four parishes, who were still struggling to become one parish, were overwhelmed and not in a position to focus on the new cathedral in the timeframe that was wished for (Larson-Miller 2010, p. 227).

Haunerland emphasizes the fact that the anthropological turn has had consequences as well for the deconsecration rite: not just the legitimate and "objective" enactment of the rite is the point of focus anymore, but more so the spiritual benefit of the faithful. This also means, according to Haunerland, with reference to Sacrosanctum Concilium 14 and 69, that the participatio actuosa of the affected parish members is a prerequisite for any deconsecration rite (Haunerland 2016, pp. 74-75). Whereas in older rites, the acting of the clergy, according to Haunerland, was the main focus, even in those rites the involvement of the parish members as the ones who also transferred images and relics from the former church to the new church was an element that was clearly mentioned (Haunerland 2011, p. 249).

Closure rites nowadays, according to Weldon, consist of the following elements: a procession to the new church with the host and other symbols such as the paschal candle, the removal of relics, the crucifix and other objects, stripping and washing of the altar, walls and ambo, remembering the 
deceased, a closing blessing near the baptismal font, and the closing and sealing of the doors (Weldon 2004, pp. 128-31). According to Leonhard, the demolition of or damage to a church building has been an immense indication, throughout the centuries, for the annulment or reduction in the sacredness of a place, and therefore an important part of deconsecration rites consists of the stylized and minimalized demolition of the building. For this reason, according to Leonhard, candles and candlesticks are occasionally tilted, or in the past, a part of the altar was purposely damaged (Leonhard 2012, p. 134). Leonhard critiques the fact that such "comparatively meaningless" rites, such as tilting candlesticks or the issuing of a bishops' decree, which involve human acting, could undo the auratic sacredness, by which he means a sacredness that can be discovered ("vorgefunden") in the world, and that is not manmade. Moreover, Leonhard points to the fact that a deconsecration rite presumes that the auratic sacredness can be undone by means of demolition. He regards the stipulation in historical texts that prescribe the erection of a crucifix at the site of the demolished church as an indication for the uncertainty surrounding whether or not the deconsecration ("Entheiligung") of a place even can or should be accomplished (Leonhard 2012, pp. 127-34). According to Leonhard, any attempt to eradicate the sacredness of a space is prone to fail since what is to be eradicated is perceived in very diffuse manners by the participants, if they even believe that said sacredness can be eradicated at all (Leonhard 2012, p. 148).

Winfried Haunerland points to the fact that the current liturgical books are not helpful when it comes to the question of whether or not a liturgical celebration that ritually marks the ending of the liturgical use of a church building could or should be performed (Haunerland 2016, p. 68). The substantial difference between the grandiose festive first use of a new church and the administrative act that marks the end of the use is, in Haunerland's assessment, hardly appropriate (Haunerland 2016, pp. 68-69). With reference to such an elaborate ritual start of a church building, Haunerland concludes that its ending should also be ritualized in an appropriate form (Haunerland 2011, p. 245). Haunerland has designed, on commission of the German Bishops Conference, a "model rite" for the deconsecration of churches (Zimmerhof 2012, p. 54; Ritus Anlässlich der Profanierung Einer Kirche 2003). Since this rite is the proposed "model rite"-it is not a compulsory form (Haunerland 2011, pp. 246-47) - for Roman Catholic church deconsecration in Germany, I will discuss this rite in more detail here.

For Haunerland, the historical ritual preoccupation with the altar in deconsecration rites should not be reinstated, but, nevertheless, the memory thereof should enforce a reverent dealing with sacred places and objects today. The same applies to the reverence for statues and images, as it is expressed in some of the descriptions of the historical rites (Haunerland 2016, pp. 76-77). Another point that Haunerland furthermore stresses is the importance of the liturgy in a pastoral sense, since the process of church conversion is often a painful one. Here, the transferal of the relics and statues and images in a procession to the new church should function as the start of a new chapter in a new home (Haunerland 2016, pp. 77-78; Haunerland 2011, p. 247). As churches are usually used liturgically right up until the moment they are taken out of liturgical use, the last Mass should be celebrated just before the church is deconsecrated. Haunerland also feels it is sensible to read the profanation decree out loud, not as a means to provide information, but as a performative act in which the public proclamation of the decree actually effects the bishops' decision (Haunerland 2016, pp. 78-79). Here, it is implied that this performative act should function as a speech act (Austin 1962) and that this act has the power to create another reality, namely make the sacred space into a profane place by saying these words out loud. Due to the church functioning as the custodian of the Eucharist in the tabernacle and the sanctuary lamp functioning as a sign of its presence, Haunerland proposes that the ciborium is taken out of the tabernacle and carried out of the church and that the light is extinguished as a sign that this space will no longer be used for liturgical means. Furthermore, he suggests the consideration to celebrate the Eucharist as a way of thanksgiving or read a votive Mass for the titular saint, since the patronage ceases to exist (Haunerland 2016, pp. 79-80). Haunerland puts considerable emphasis on the future outlook, which could be expressed in a festive procession of the parish members as they transfer the 
ciborium to the new church. He also puts forth the option of transferring other objects of meaning to the new church. As a concluding rite in the new church, Haunerland suggests requesting God to let the faithful find a new home there and that both communities may be successful in their communal path thereafter. A final suggestion he makes is to sing a song of praise for the statue or image of the former patron saint in the new church to show that the saint and the community have arrived in the new parish. An informal gathering in which hopes and fears are discussed should conclude it all (Haunerland 2016, pp. 80-82; Haunerland 2011, p. 245).

In the description of the rite, Haunerland discerns two parts, the first he names "The last Eucharistic celebration—the farewell rite" ("Die letzte Eucharistiefeier-der Abschiedsritus") and the second part he names "Procession and final station in the 'new' church-a rite of passage" ("Prozession und abschließende Statio in der 'neuen' Kirche-ein Übergangsritual"). This second header refers to the theory of the French ethnologist Arnold van Gennep. To Haunerland, the deconsecration rite should indeed function as a rite of passage, it should not focus too much on leaving the old church, but more so on a new phase of being church. He applies the tripartite structure of Van Gennep to the deconsecration ritual: 1. separation rite: church deconsecration, extinguishing of the sanctuary lamp, procession out of the church, 2. transition rite: procession, and 3. incorporation rite: setting up the image of the patron saint in the new church, liturgical completion, and the repositioning of the ciborium. If it is not possible to have a procession towards the new church, the ciborium should nevertheless be transferred to another church. The incorporation in the new church could take place at a later point in time by celebrating Mass there for the first time. The rite Haunerland designed aims at helping people to cope with the pain of the valediction and their sadness and enabling people to become mutually active once again (Haunerland 2011, p. 247; Haunerland 2016, pp. 81-82). The officiator of the rite should ideally be the diocesan bishop, according to Haunerland, since a bishop is the person who originally dedicated the church and since he is the one who decides whether or not a church is to be taken out of liturgical use. Only if the diocesan bishop is indisposed, another bishop, or if that is not possible, another priest, could perform the last ritual. The officiator should ideally celebrate the last liturgy with those priests who were responsible for the liturgical celebrations in that church (Haunerland 2016, pp. 82-83).

Clemens Leonhard also underscores the fact that there is a huge discrepancy between the dedication of a church and its deconsecration and therefore there is a need to undertake ritual action if a church is to be deconsecrated (Leonhard 2012, pp. 131-32). He distinguishes three categories of reasons for designing deconsecration rites nowadays: first, there is an interest for the presentation and publication of legal instruments that are regarded as the only effective means in this context, second, there is an interest for the desacralization of sacred spaces and places as well as for the removal or disposal of the sacred objects within them, and third, there is an interest in communal farewell celebrations for church buildings (Leonhard 2012, p. 126). Leonhard discerns between deconsecration rites ("Profanierungsrituale") and farewell ceremonies ("Abschiedsfeiern"). Rites that aim to dissolve the dedication (legally) or to annihilate the sacredness of a building are deconsecration rites and they differ from farewell ceremonies in the sense that deconsecration rites, in contrast to farewell ceremonies, do not do justice to the social and ecclesiastical reality (Leonhard 2012, pp. 126-27). According to Leonhard, only the last designated use of the church effects the decommissioning of the church building. The eradication of sacredness, a ritual act of demolition, the transfer of sacred objects, or the issuing of a decree do not effect this. Therefore, according to Leonhard, the superior way of any liturgical celebration in this context should be a farewell ceremony and not a liturgical staging of the deconsecration of the church. The farewell ceremony should preferably incorporate a Mass because it is to assume that the celebration of the Mass was the main reason for people using the church building and also because the use of a church starts with the celebration of the first Mass and in this sense a concluding Mass bridges the start and the end of the use (Leonhard 2012, pp. 147-48).

In his analysis of the rite designed by Haunerland, Leonhard assesses that the transfer of the host, relics, statues, etc., from the former church to the new church implies that the sacredness is also transferred or even ceases to exist when it is removed. He doubts whether these acts can annihilate the 
auratic sacredness and puts forth that this implies a mobile understanding of sacredness that does not take into consideration a specific part of the buildings use, namely its purpose as an assembly room for the faithful. The transferal of objects also suggests that the sacredness of the space predominantly consists of it being a container of sacred matter. The explicitly desired procession within this ritual design is also ambivalent, since a procession is not a prerequisite for deconsecrating a church and this makes Leonhard ponder whether or not the people in the procession should only be regarded as decorum for the sacred objects they transfer and that they actually play a secondary role (Leonhard 2012, pp. 140, 149). He also problematizes the bishop as being the one who celebrates the last Mass, the bishop is not a member of the assembly and performs an act that in most cases people do not wish to be performed, namely the closing of their church. The bishop thereafter leaves without suffering a loss in the same sense the parishioners do and he does not have to deal with the everyday problems of the parish (Leonhard 2012, p. 142). Furthermore, since the issuing of the decree is, according to canon law, the legitimate way to deconsecrate a church, and requires no additional liturgical staging, the participation of the bishop is not required in a farewell celebration. In this way, having the bishop act as the officiator of the last rite could lead to the erroneous assumption that this rite actually is a rite that reverses the rite of church dedication (Leonhard 2012, pp. 145-46, 148). Leonhard prefers a last celebration without any form of ritual demolition or ritual transfer of objects, he proposes a celebration that deals with feelings of thankfulness and sadness, without triumphalism (Leonhard 2012, pp. 146-47). He indicates that ritual designs that try to instill a sense of hope and that predominantly focus on the future are simply out of place and he paints the following picture:

"The procession of the faithful through the neighborhood, which is witnessed by the other residents on the sidewalk in incomprehension, is no victory parade. The church building is not given up for a new building, but abandoned for demolition or reuse. The churchgoers do not move out of the slave house towards the promised land, but give up territory that once was filled with life forever. The refill of these empty spaces with shelves and containers for the ashes of the deceased is also a powerful sign pointing in the same direction. At least the Catholic church in Germany stages the death of the national church vividly by using the church buildings that the living no longer have use for, for putting on display the mortal remains of their former members." ${ }^{1}$ (Leonhard 2012, pp. 142-43).

Leonhard refers here to the West German popular form of the reuse of churches into columbaria. As Paul Post remarks, the Roman Catholic church uses processions as ways of "occupying" the public domain and thus profiling itself (Post 2010, p. 201). If, as Leonhard states, such processions are actually incomprehensible for the bystanders that witness them, one could indeed ask if the performative message the church wants to send is in fact the opposite message senders receive.

Haunerland is aware that the deconsecration rite he proposes is no substitute for the mourning work that must be done to alleviate the hurt and anger people may feel (Haunerland 2011, pp. 247-48). Haunerland responds to the critique uttered by Albert Gerhards who states, with reference to deconsecration rites, that a church cannot lose its sacredness just by declaring that the space is a profane space from now on, that although this critique may be just, the question still remains of what one should do if church closure is inevitable. Even if one is critical of church closure, the situation still demands that one reflects on the way in which one deals with those affected (Haunerland 2011, pp. 250-52).

1 “Der Zug der Gläubigen durch das Stadtviertel, den dessen übrige Bewohner vom Bürgersteig aus verständnislos betrachten, ist kein Triumphzug mehr. Das Kirchengebäude wird auch oft nicht zum Neubau, sondern zum Abriss oder zur Umwidmung aufgegeben. Das Kirchenvolk zieht nicht aus dem Sklavenhaus in Richtung des gelobten Landes aus, sondern gibt Territorium, das es früher einmal mit Leben gefüllt hat, für immer auf. Die Auffüllung solcherart freiwerdender Leerräume mit Regalen und Behältern für die Asche der Toten ist ebenfalls ein mächtiges Zeichen, das in dieselbe Richtung deutet. Zumindest inszeniert die katholische Kirche in Deutschland den Tod der Volkskirche anschaulich, indem sie in den Kirchengebäuden, die die Lebenden nicht mehr benützen, die sterblichen Überreste der ehemaligen Mitglieder zur Schau stellt.“ Translation: KdW. 


\section{Deconsecration Rites: Future?}

Contrary to what one may assume, the deconsecration of church buildings is not as straightforward as one would think, not even with reference to canon law as the contradictory interpretations of Huels and Schöch with reference to what may be considered "grave reasons" for church deconsecration or the position of substantial financial donors in such cases show. In addition to this, the fact that a church, even after it has been deconsecrated according to canon law, may not be used in a "sordid" way, leaves room for the interpretation that the church recognizes that said sacredness is not completely annulled by the issuing of the profanation decree, something that the historical practice of erecting a crucifix at the place where a church once stood as a remembrance, as Leonhard points out, also alludes to.

With regard to deconsecration rites it is noteworthy that a shift has taken place in the perception of reasons why such a rite should be conducted. In contrast to historical requirements that mainly focused on such acts for the purpose of the "legitimate" way of relegating the church to profane use, nowadays the wellbeing of the affected parishioners seem to be the main reason for the performance of such rites. One element that Leonhard clearly points out and that seems to be a complicating factor for the success of such rites is the fact that such a rite is, in the eyes of the church officials, not necessary for the effective deconsecration of a church building. The "staging" of the deconsecration could be considered a meaningless rite since it has no effect in the sense of canon law, it does not bring about the profane status of a church building. The mixture of the deconsecration act and rites that aim to help parishioners cope with feelings of anger and sadness creates a ritual muddle. Leonhard's proposal of not mixing these two different acts seems to be a solution in cleaning up this ritual muddle.

It can also be questioned whether or not the official Roman Catholic church should issue official ritual regulations for a deconsecration rite at all. There obviously is a ritual void and a ritual need, but the necessity for any prescribed and universally applicable form may be questioned since every case of church closure or reuse and the history of a particular church is quite individual. Whereas in one case the relegation of a church to profane use may cause a lot of pain and sorrow, in another case it may not be all too painful, and parishioners may even feel freed from a burden. Individual cases may ask for individual solutions. In the case of St. John Baptist in Altenessen (De Wildt 2019), the opponents of church closure I interviewed expressed being far too angry to attend any farewell celebration and said that they would not attend such a last ceremony as a sign of protest.

It is also noticeable that two German scholars of liturgical studies, Clemens Leonhard and Winfried Haunerland, chose the following titles, which are phrased in the form of questions, for their respective contributions on the topic, Leonhard: "Profanierungsritual oder Abschiedsfeier?": "Deconsecration Rite or Farewell Ceremony?" and Haunerland: "Abschiedsfeier oder Übergangsritual?": "Farewell Ceremony or Rite of Passage?" Both Haunerland and Leonhard seem to underscore, with the choice of these titles, the unclarity of what actually entails church deconsecration and what the status is or should be of the rites involved here. This unclarity is exemplary for the current situation regarding church closure: what does it mean to deconsecrate a church building, notwithstanding the fact that the deconsecration of a church building is a matter of canon law too, is a juridical discourse alone able to do justice to this multilayered phenomenon? Does a church building cease to be a sacred space by the issuing of a decree? Does it require an "official rite" to undo the sacredness of the church building and thus, if that is even ritually possible, transform it into a profane space? Does the design of a rite that takes the feelings of those affected into consideration suffice as a means to appease all those affected?

Moreover, the design of a rite by a ritual expert, even if it does not aim to be a rite of the sort that says one size fits all, is a top down approach that does not take into consideration the particularity of each and every specific case with its own history. If such a rite is meaningless in the sense of canon law and actually unnecessary to deconsecrate a church - if it is only performed for the good of the souls-should such a rite even be performed at all? The shift towards more subject orientation in ritual designs for church deconsecration seems incongruent with the liturgical approach in Roman Catholic rites for dedicating a church building, which are more object orientated, but this shift can also be regarded as an effort to keep in pace with the emotional needs of the faithful. However, do the 
faithful feel taken seriously in their emotional needs if they are aware that they are taking part in a ritual that, in the logic of the church they adhere to, is completely unnecessary and has no effect?

In conclusion, it can be said that the diverse rationales that underlie the concept of sacredness within the Roman Catholic church complicate the deconsecration of church buildings. Furthermore, the question of what constitutes a successful deconsecration should be answered first. However, whom should be asked? The church as an institution? If that is the case, one could simply refer to canon law, since a juridical act suffices. If one were to ask the faithful, more than a juridical act would probably be needed. Nevertheless, if a rite has no official status for the church as an institution that those affected adhere to, it will remain questionable if such a rite indeed can fulfil the needs of those faithful.

The simple dichotomy between sacred and profane does not reflect the more complex reality that underlies the problem church deconsecration poses. If reality is far more complex than this dichotomy presumes, then the way in which a transformation of sacred space should be managed ritually is also complex and multilayered and should be handled in an individual and differentiated manner. Making and marking a clear distinction between the act of church deconsecration and the last farewell celebration is helpful in the sense that it clears up the current ritual muddle. The intra-ecclesiastical conviction that an act of deconsecration is required could be met by the issuing of a decree. This should then be differentiated from the farewell ceremony, which should be explicitly understood as a ritual that does not bring about the unmaking of sacred space in the sense of canon law, but can be helpful in tending to pastoral needs. These pastoral needs can be very diverse, a need to deal ritually with anger and hurt, a need to ritually mark the end of the liturgical use, a need to ritually frame a new beginning, and even a mixture of all these and other elements. Therefore, a bottom-up approach of ritual design of those affected would be the obvious answer. A ritual design that, already in the preparation phase, considers the needs of those affected and tries to frame this ritually. Church closure is a process that cannot be effected at a certain point in time. In analogy: when does one actually let go of a deceased loved one? When that person actually dies? During the farewell service? In the grieving process afterwards? Or perhaps one is not able to ever really say goodbye.

Funding: This research was funded by the GERMAN RESEARCH FOUNDATION, grant number 387623040, research unit FOR 2733: "Transformation of Sacred Space: Function and Use of Religious Places in Germany".

Conflicts of Interest: The author declares no conflict of interest.

\section{References}

Austin, John Langshaw. 1962. How to Do Things with Words: The William James Lectures Delivered at Harvard University in 1955. Oxford: Oxford University Press.

Cardinal Piacenza, Mauro, and Celso Morga Iruzubieta. 2013. Official Documents of the Holy See: Letter from the Congregation for the Clergy and Procedural Guidelines for the Modification of Parishes and the Closure, Relegation and Alienation of Churches. The Jurist: Studies in Church Law and Ministry 73: 211-19.

Code of Canon Law. 1983. Book IV: Function of the Church. Part III: Sacred Places and Times. Title I: Sacred Places. Libreria Editrice Vaticana. Available online: http://www.vatican.va/archive/cod-iuris-canonici/cic_ index_en.html (accessed on 13 August 2020).

De Wildt, Kim. 2019. Synagogues and Churches: The Transformation of the Religious Cityscape in Germany since 1990. bfo-Journal 5: 40-60.

De Wildt, Kim, and Robert J. J. M. Plum. 2019. Kirchenumnutzung. In Handbuch der Religionen. Kirchen und Andere Glaubensgemeinschaften in Deutschland und im Deutschsprachigen Raum. Band 2. 60. Ergänzungslieferung. Edited by Michael Klöcker and Udo Tworuschka. Hohenwarsleben: Westarp Science-Fachverlage, pp. 1-30.

De Wildt, Kim, Martin Radermacher, Volkhard Krech, Beate Löffler, and Wolfgang Sonne. 2019. Transformations of 'Sacredness in Stone': Religious Architecture in Urban Space in 21st Century Germany-New Perspectives in the Study of Religious Architecture. Religions 10: 602. [CrossRef] 
Dedication of a Church and an Altar. 1978. Revised 1989. International Committee on English in the Liturgy, Inc. Available online: https://www.liturgyoffice.org.uk/Resources/Rites/RDCA.pdf (accessed on 14 August 2020).

Della Dora, Veronica. 2016. Infrasecular geographies: Making, unmaking and remaking sacred space. Progress in Human Geography 42: 44-71. [CrossRef]

Gerhards, Albert. 2020. Kirchenräume avantgardistisch bewahren. In Heilige Kunst 2018/2019. Ostfildern: Schwabenverlag, in print.

Guidelines. 2019. Dio non Abita più Qui? Dismissione di Luoghi di Culto e Gestione Integrate dei Beni Culturali Ecclesiastici/Doesn't God Dwell Here Anymore? Decommissioning Places of Worship and Integrated Management of Ecclesiastical Cultural Heritage. Edited by Fabrizio Capanni. Roma: Editoriale Artemide s.r.1., pp. $253-87$. Available online: http://www.cultura.va/content/dam/cultura/docs/pdf/beniculturali/guidelines.pdf (accessed on 23 September 2020).

Haunerland, Winfried. 2011. Kein Abschied ohne Neubeginn: Pastoralliturgische Herausforderungen anlässlich der Aufgabe einer Kirche. In Kirchenbauten in der Gegenwart: Architektur zwischen Sakralität und Sozialer Wirklichkeit. Edited by Angelika Nollert, Matthias Volkenandt, Ruth-Maria Gollan and Eckhard Frick. Regensburg: Verlag Friedrich Pustet, pp. 245-52.

Haunerland, Winfried. 2016. Liturgie und Kirche: Studien zu Geschichte, Theologie und Praxis des Gottesdienstes. Regensburg: Verlag Friedrich Pustet.

Huels, John M. 2000. Title I: Sacred Places [cc. 1205-1243]. In New Commentary on the Code of Canon Law. Edited by John P. Beal, James A. Coriden and Thomas J. Green. New York: Paulist Press, pp. 1425-41.

Larson-Miller, Lizette. 2010. Place and Community: The Sacramentality of Sacred Space and the New Cathedral of Oakland, California. In Holy Ground: Re-inventing Ritual Space in Modern Western Culture. Edited by Paul Post and Arie L. Molendijk. Leuven: Peeters, pp. 211-34.

Leonhard, Clemens. 2012. Profanierungsritual oder Abschiedsfeier? In Tot in die Kirche? Rechtliche und Liturgische Aspekte der Profanierung von Kirchen und Ihre Umnutzung zu Kolumbarien. Edited by Clemens Leonhard and Thomas Schüller. Regensburg: Verlag Friedrich Pustet, pp. 126-49.

Literatur zu Kirchenumnutzungen. n.d. Schweizer Kirchenbautag. Universität Bern. Available online: https://www.schweizerkirchenbautag.unibe.ch/unibe/portal/fak_theologie/mico_kirchenbau/content/ e547963/e825799/e825832/e825834/LiteraturKirchenumnutzungen_ger.pdf (accessed on 21 September 2020).

Pahud de Mortanges, René. 2007. Die Normen des katholischen und evangelischen Kirchenrechts für die Umnutzung von Kirchen. In Bau und Umwandlung Religiöser Gebäude. Le Patrimoine Face à L'immobilier et la Construction. Edited by René Pahud de Mortanges and Jean-Baptiste Zufferey. Zürich: Schulthess Juristische Medien, pp. 183-99.

Paprocki, Thomas J. 1995. Parish closings and administrative recourse to the Apostolic See: Recent experiences of the Archdiocese of Chicago. The Jurist: Studies in Church Law and Ministry 55: 875-96.

Post, Paul. 2010. Voorbij het Kerkgebouw: De Speelruimte van een Ander Sacraal Domein. Heeswijk: Abdij van Berne.

Post, Paul. 2019. Disappearing Ritual: Redundant Church Buildings. In Absent Ritual: Exploring the Ambivalence and Dynamics of Ritual. Edited by Paul Post and Martin Hoondert. Durham: Carolina Academic Press, pp. $45-62$.

Ritus Anlässlich der Profanierung Einer Kirche. 2003. Ritus Anlässlich der Profanierung Einer Kirche. In Umnutzung von Kirchen: Beurteilungskriterien und Entscheidungshilfen. Edited by Deutsche Bischofskonferenz. (Arbeitshilfen 175/24. September 2003). Bonn: Sekretariat der Deutschen Bischofskonferenz, pp. 26-29.

Schöch, Nicholas. 2007. Relegation use of churches to profane use (c. 1222, sec.2): Reasons and procedure. The Jurist: Studies in Church Law and Ministry 67: 485-502. [CrossRef]

Schüller, Thomas. 2012. Die Umnutzung von Pfarreien zu Grabeskirchen: Kirchenrechtliche Aspekte. In Tot in die Kirche? Rechtliche und Liturgische Aspekte der Profanierung von Kirchen und ihre Umnutzung zu Kolumbarien. Edited by Clemens Leonhard and Thomas Schüller. Regensburg: Verlag Friedrich Pustet, pp. 261-78.

Simons, Thomas G. 1998. Holy People, Holy Place: Rites for the Church's House. Chicago: Archdiocese of Chicago, Liturgy Training Publications.

Umnutzung von Kirchen. 2003. Umnutzung von Kirchen: Beurteilungskriterien und Entscheidungshilfen. Edited by Deutsche Bischofskonferenz. (Arbeitshilfen 175/24. September 2003). Bonn: Sekretariat der Deutschen Bischofskonferenz. 
Weldon, Michael. 2004. A Struggle for Holy Ground: Reconciliation and the Rites of Parish Closure. Montgomery County: Liturgical Press.

Zimmerhof, Christine. 2012. Liturgie der Kirchenprofanierung in Geschichte und Gegenwart. In Tot in die Kirche? Rechtliche und Liturgische Aspekte der Profanierung von Kirchen und ihre Umnutzung zu Kolumbarien. Edited by Clemens Leonhard and Thomas Schüller. Regensburg: Verlag Friedrich Pustet, pp. 9-125. 